\title{
A migráció női arca
}

\section{The female side of migration}

\section{LIPTÁK KATALIN, MATISCSÁKNÉ LIZÁK MARIANNA}

LIPTÁK Katalin: egyetemi adjunktus, Miskolci Egyetem, Világ- és Regionális Gazdaságtan Intézet; 3515 Miskolc-Egyetemváros; liptak.katalin@uni-miskolc.hu MATISCSÁKNÉ LIZÁK Marianna: tanársegéd, Eszterházy Károly Egyetem, Gazdaságtudományi Intézet; 3300 Eger, Egészségház utca 4.; matiscsakne.marianna@uni-eszterhazy.hu

KULCSSZAVAK: migráció; nők; nemek közötti eltérések, kérdőíves felmérés

ABSZTRAKT: A tanulmányban azt vizsgáljuk, hogy van-e különbség Magyarországon a nők és a férfiak vándorlási tendenciája között. Bizonyított, hogy a migrációs hullámnak nemzetközi szinten egyre több a női résztvevője, sokszor kényszermegoldásként választják az elvándorlást, a szegénységtől vagy a munkanélküliségtől való menekülésként. A cikkben rávilágítunk arra, hogy ez a tendencia hazánkban is érvényes-e. Hipotézisünk szerint nembeli különbség van a migrációs folyamatokban, és részben más tényezők befolyásolják egy nő migrációs döntését. Kérdőíves felmérést végeztünk a külföldön élő és dolgozó, Magyarországról elvándorolt állampolgárokkal. A felmérés eredménye megerősítette azt a feltételezésünket, hogy a női migrációnak két fő fajtája alakult ki: az egyik eset, amikor az egyedülálló nő önállóan hozza meg a döntést és egyedül vág bele a külföldi munkavállalásba; a másik esetben a férjét, párját külföldre követi a nő és közösen hozzák meg a döntést. A távolság hatásának vizsgálata újszerü eredményt hozott, ugyanis a Magyarországtól földrajzilag távolabbra vándorolt nők külföldi életüket véglegesnek tekintik, hazatérésükre kisebb az esély.

Katalin LIPTÁK: assistant professor; Institute of World and Regional Economics, University of Miskolc; H-3515 Miskolc-Egyetemváros, Hungary; liptak.katalin@uni-miskolc.hu

Marianna MATISCSÁKNÉ LIZÁK: assistant lecturer, Institute of Economic Sciences, Eszterházy Károly University; Egészségház utca 4., H-3300 Eger, Hungary; matiscsakne.marianna@uni-eszterhazy.hu

KEYWORDS: migration; women; gender differences; questionnaire

ABSTRACT: This study examines whether there are differences between women and men in their relationship with migration. It has already been proven that today more and more women becomes part of the international migration wave. In most of the cases they move in order to escape poverty and unemployment. In this article we shed light on migration's current situation in Hungary. In order to test our hypothesis, we surveyed citizens who moved from Hungary and are working abroad. The result of this research confirmed our hypothesis that women's migration can fall into two main types. First, there are women who make their own decision as an individual and decide to work abroad alone. Second, there are women who follow their husband or partner and make decisions together.

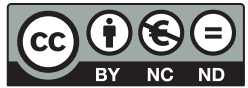


The goal of this research was to discover the characteristics of women's migration and to decide if there is non-specific progress or not. To achieve this goal, we used a primer questionnaire.

In our survey, we dealt differently with the answers coming from women and men because our main aim was to examine the reasons and tendencies of women's migration. The survey was filled in online with a snowball method. All in all we received 105 answers in the first half of May, 2017, 70 of which coming from women. It happened only by accident that twice as many women answered as men. However, this ratio was adequate to handle men's answer as the control group.

The answers have been processed using Microsoft Excel and IBM SPSS Statistics 24. We used crosstabulation analysis to find out the relationship between temporal and permanent abroad stay. We assessed this relation using the Chi-square of Pearson. We also made a variance analysis in order to discover influencing factors of migration decisions and to shed light on the sex differences. Furthermore, we also made a factor analysis on decision influencers.

Based on our research and assessments, we argue that there are two main motivational factors behind women's migration. First, the desire for gaining experience and, second, the lack of job opportunities. Most of the women are married or have a relationship and only consider returning home. Men played an important role in the decision making process that lead to mobility. Single women, in general, are younger and definitely want to return to Hungary after some years. We can say also argue that for women, who went far away from Hungary, migration was a final choice, and are not considering going back.

\section{Bevezetés}

Az emberi helyváltoztatás vagy vándorlás nemcsak a közvélekedésnek, hanem a tudományos gondolkodásnak is egyre inkább a színterévé válik. A migráció fogalmi ismérveinek számos megközelítése van, de a migráció definíciójának középpontjában általában az emberi magatartás, a lakóhely megváltoztatása, a költözés vagy a vándorlás áll (Hautzinger, Hegedüs, Klenner 2014). Ezen emberi magatartások hátterében Dabasi-Halász (2009) az általános társadalmi, gazdasági, politikai folyamatok szerepét is hangsúlyozza. Tanulmányunkban e társadalmi folyamatok közül a nemek közötti különbségekre fókuszálunk.

Cikkünkben a Dabasi-Halász-féle migránsfogalmat használjuk, miszerint migránsnak tekintheto „minden olyan egyén vagy csoport, teljes szervezet, aki vagy ami állandó vagy ideiglenes jelleggel lakó-, illetve tartózkodási helyét földrajzi viszonylatban megváltoztatja, tekintet nélkül cselekvésének okára." (Dabasi-Halász 2009, 8.)

A migráció meghatározható a benne részt vevők száma, valamint földrajzi távolsága szerint. A vándorlás mint emberi magatartás mindig természetes személyhez, a migránshoz kapcsolódik, hiszen ő „mozog”. Ennek nem mond ellent, hogy létezik csoportos migráció is, amikor többen indulnak el, együtt vándorolnak például családtagok vagy barátok, remélve, hogy egy közös végcélhoz érve könnyebben be tudnak illeszkedni. Előbbiek mellett megjelent a tömeges vándorlás, amikor valamilyen negatív természetü esemény hatására térben és időben egyszerre sok személy vesz részt a vándorlásban (Gödri 2010; Hautzinger, Hegedüs, Klenner 2014). Cseres-Gergely (2003, 54.) szerint a „területi egység 
megválasztása alapvető hatással van arra, hogy kit tekintünk migránsnak. Leggyakoribb az országok közötti, valamint az országon belüli nagyobb régiók közötti migráció vizsgálata." Magyarországon az 1970-es években főleg a férfiak munkavállalási célú elvándorlása volt jellemző, az 1990-es években jelentek meg nagyobb számban a migráns nők (Gödri 2005).

A közgazdaságtani vizsgálatok sokáig nem fordítottak figyelmet a társadalmi nemek közötti különbségekre. Ebben változást a feminista közgazdaságtan jelentett: híveinek véleménye szerint a bérmunka mellett a reprodukció mint munka vizsgálatára volna szükséges nagyobb hangsúlyt fektetni (Michalitsch 2011). Ez a szemlélet az elmúlt évtizedekben a migrációkutatásban is előtérbe került, mivel a nők migrációs tapasztalata eltér a férfiakétól. A nők migrációs hajlandóságát nagymértékben befolyásolja családi állapotuk, mivel egy egyedülálló nő könnyebben indul el a külföldi munkavállalás „útján”, mint egy többgyermekes anya. További érdekes elemzési kérdés a befogadó ország hozzáállása a migránsokhoz. Bizonyos országokban a bevándorló nők jogai eltérnek a bevándorló férfiak jogaitól, és a nőket esélyhátrány éri. Ez a hátrány gyakran válik többszörössé, hiszen a munkavállalás terén is hátrányban vannak (Melegh, Kovács, Gödri 2009).

Tanulmányunkban egy kérdőíves felmérés alapján vizsgáljuk a magyarországi migrációs folyamatokat, amelyben a fókuszt a nők és a férfiak közötti különbségekre helyezzük.

\section{A migráció genderszempontú vizsgálatai}

A migrációról szóló tanulmányokban a nemek szerinti elemzés az 1970-es években jelent meg. A nemet ekkor egyéni szinten, a születéskor meghatározott statikus kategóriaként fogalmazták meg, az „adjunk hozzá nőket és keverjük össze" megközelítését alkalmazták (Hondagneu-Sotelo 2000; Indra 1999; Kofman et al. 2000), amelyben a férfi és a női bináris tényezőként jelent meg, a megállapítások egy része pedig a férfiak tanulmányozásából történő általánosításból származott. A nemet olyan társadalmi tényezőnek tekintették, mint például az életkort, amelyet egyszerủen hozzá lehet adni a migrációt magyarázó változókhoz; vagy - ahogy Moch (2005) megjegyzi - egyszerüen nem tekintették meghatározó, dinamikus tényezőnek.

Ennek a szemléletmódnak a magyarázata Nawyn (2010) és Cantu (2001) szerint az, hogy a nem feminista migrációkutatók a gazdasági folyamatokat makroszinten vizsgálták, amelynek így nagyobb magyarázó erőt tulajdonítottak, mint az egyéni szintű jellemzőknek és a nemekhez való tartozásnak. A feminista szemléletű migrációkutatók viszont amellett érvelnek, hogy a társadalmi nem többet jelent az egyéni szintnél (és több, mint egy kontrollváltozó), ezzel összefüggésben pedig a kvantitatív és a kvalitatív megközelítések 
erősebb integrációjára van szükség (Curran et al. 2006). Ezzel a szemléletváltással párhuzamosan a migráció genderszempontú vizsgálata számos területen új eredményeket hozott.

A tanulmányok rámutattak a migráció nők és férfiak közötti részarányainak eltolódására. Számos országban megfigyelhető a munkavállalási célú külföldi migráció mint megélhetési stratégia, valamint a változó családon belüli munkamegosztás. Nepálban például az ország GDP-jének több mint negyedét a külföldi hazautalások tették ki (elsősorban az Arab-öböl menti országokból), a külföldön munkát vállalók többsége férfi (Grossman-Thompson 2016). Todd és szerzőtársai (2017) ezzel szemben a Tanzániában élő nők és fiatalok mobilitásáról megállapították, hogy a fiatal nők sokkal inkább részesei a mobilitásnak, mint a férfiak, ezt pedig a nők nagyobb felelősségvállalásával (women's empowerment) magyarázták. Nepálban a nők a törvényi elő́rások miatt sem vehetnek részt a migrációban: az ország a 30 év alatti nőknek megtiltja a külföldi munkavállalást az Arab-öböl menti országokban, ezzel a szexuális bántalmazástól és egyéb erőszaktól kívánja megvédeni őket (Grossman-Thompson 2016).

Az utóbbi 30 évben az önálló nők migrációja is megjelent, akik fizetett munkával rendelkeznek és így anyagilag nem függnek a férfiaktól. Ezekben az esetekben a gazdasági okok mellett a nők önállóságra törekvése vezethet migrációhoz, illetve fordítva: a migráció jelentősen hozzájárul a társadalmi változásokhoz. A nők nagyobb arányú foglalkoztatása az ipari szektorban jelentős változást hozott a migrációs forgatókönyvekben (Choudhury 2017), növekszik az önállóan elvándorló nők száma: az országokon belül a falvakból az önálló nők számára megnyíló városi munkaerőpiacokra (Jesmin, Salway 2000; Kabeer, Mahmud 2004; Momsen 1993), de nemzetközi léptékben is.

A migrációs mintázatokat a családmodellek is erőteljesen befolyásolják. Kelly (2017) az iráni diaszpórát vizsgálta Svédországban, a fó hangsúlyt a migránsok gyermekeire helyezte. Eredményei szerint a hagyományos iráni családmodellt a férfiak uralják, az önálló női döntés nem jellemző. Bangladesben szintén a patriarchális családmodell az uralkodó, a nők függő helyzetben vannak a férjüktől. Így sokáig szinte csak a férfiak körében volt megfigyelhető a migráció, illetve a nők a férjüket követték ugyan külföldre, de nem vállaltak munkát (Choudhury 2013).

A termelés mellett a reprodukció nemi összefüggései is megjelentek a migrációs kutatásokban. Oso és Ribas-Mateos (2013) a transznacionális migrációs áramlások hatását vizsgálták a termelési és reprodukciós láncokra. Különös figyelmet fordítottak a globális gondozási láncokra, amikor a korábban a családon belül végzett (idős- vagy gyerek)gondozást főleg női migráns munkavállalóknak adtak át, ami új mobilitási trendeket rajzolt ki. 


\section{A kérdőíves kutatás célja és módszertana}

Kérdőíves kutatásunk célja az volt, hogy Magyarországról kivándorolt személyek körében megvizsgáljuk a nők migrációs folyamatának jellemzőit, azok nemspecifikus jellegét. A kérdőívet a válaszadók online töltötték ki, a mintát hólabdamódszerrel építettük. Összesen 105 válasz érkezett be (ezek közül 70 női és 35 férfi választ kaptunk). Az adatfelvétel 2017 májusának első felében történt. A minta legfontosabb ismérveit az 1. táblázat tartalmazza.

1. táblázat: A minta összetétele

Sample composition

\begin{tabular}{llrr}
\hline & Ismérvek & Fó & $\%$ \\
\hline Nem & Férfi & 35 & 33,3 \\
& Nő & 70 & 66,7 \\
\hline Életkor & $18-22$ év & 4 & 3,8 \\
& $23-27$ év & 33 & 31,4 \\
& $28-32$ év & 22 & 21,0 \\
& $33-37$ év & 22 & 21,0 \\
& $38-42$ év & 11 & 10,5 \\
& $43-47$ év & 7 & 6,7 \\
& 48 éves és idősebb & 4 & 3,8 \\
\hline Családi állapot & Egyedülálló & 12 & 11,4 \\
& Elvált & 4 & 3,8 \\
& Házas & 47 & 44,8 \\
& Kapcsolatban él & 42 & 40,0 \\
\hline Iskolai végzettség & Szakközépiskola, szakmunkás & 17 & 16,2 \\
& Gimnáziumi érettségi & 22 & 21,0 \\
& Diploma & 64 & 61,0 \\
& PhD vagy egyéb tudományos fokozat & 2 & 1,9 \\
\hline Állandó lakóhely típusa & Főváros & 16 & 15,2 \\
& Megyeszékhely & 47 & 44,8 \\
& Egyéb város & 22 & 21,0 \\
& Község & 20 & 19,0 \\
\hline
\end{tabular}

A válaszokat Microsoft Excel programmal és IBM SPSS Statistics Version 24 programmal dolgoztuk fel, statisztikai módszerek segítségével, amelyeket az eredmények között mutatunk be részletesen.

\section{A kérdőíves felmérés eredményei}

A válaszadó nők többsége (17 fö) 1-3 éve él külföldön, 19 fo 3-5 éve, 18 fő 5-10 éve. A több mint 10 éve külföldön élő nők száma 7, a kevesebb mint egy éve külföl- 
dön élő nők száma pedig 9 fŏ. A férfiak válaszainak megoszlása némiképp eltér a nőkétől: a legtöbben (14 fö) 1-3 éve élnek külföldön. A migrációs döntés a 20-as évek közepén született meg a legtöbb, felmérésünkben szereplő nőnél.

A női válaszadók többsége (25 fö) az Egyesült Királyságban él jelenleg, 12 fó Németországban, 8 fó Írországban, 5 fö az USA-ban, 4 fö Ausztriában és 4 fö Svájcban, a többi válaszadó (1-2 fö országonként) Szingapúrban, Chilében, Izraelben, Norvégiában és Cipruson. A mintába bekerült nők megerősítik azt a migrációs tendenciát, miszerint a legtöbb magyar az Egyesült Királyságba, Németországba és Írországba érkezik munkavállalási célból és ott települ le. A válaszadó nők 50\%-a házasságban él, feltehetően a férjüket követték a külföldi munkavállalásban. A kapcsolatban élő nők száma szintén magas (23fó), életkorukat tekintve nagyobb arányban 28-32 év közöttiek, feltehetően ők is a párjukat követték vagy közös döntés eredményeképpen vállalták a külföldi életet. Az egyedülálló nők száma alacsony volt a mintában (9fö), ők jellemzően 23-27 évesek.

Megvizsgáltuk, hogy a válaszadóink tervezik-e a végleges hazatérésüket. A férfiak 51,4\%-a és a nők 32,9\%-a még gondolkodik a hazatérésen. A férfiak 37,1\%-a és a nők relatív többsége egyáltalán nem tervezi a hazatérést. Mindkét nem esetében 11,4\% gondolkodik a közeljövőben a hazatérésen. Ezeket a nemek között különbségeket viszont a statisztikai számításaink nem mutatták szignifikánsnak: a Pearson-féle khí-négyzet megfigyelt értéke 3,742 $\left(\mathrm{d}_{\mathrm{f}}=3\right.$, sig=0,291).

A hazatérés valószínűsége erősen függ a válaszadó nők külföldön eltöltött éveinek számától, családi helyzetétől és a kivándorlás országától. A 20-as évek elején járó (általában egyedülálló vagy kapcsolatban élő) nők kevesebb, mint egy éve tartózkodnak külföldön és a válaszaik alapján ők még 3-5 éven belül nagyobb arányban tervezik a végleges hazatérést. Kivándorlásuk okaként a munkalehetőségek hiányát és a magyarországi alacsony életszínvonalat jelölték meg, „pénzgyűjtési” célzatból vállalták a nem végleges migrációt. A válaszadó nők közül 34 fó $(48,6 \%)$ egyáltalán nem tervezi a végleges hazatérést Magyarországra, a minta alapján ők többnyire házasok vagy kapcsolatban élnek, 40-es éveikhez közel járnak és 5-10 éve vagy még régebben tartózkodnak külföldön. Ők alkotják azt a csoportot, akik elégedettek a külföldi munkájukkal, életkörülményeikkel. Nem kérdeztünk rá honvágyukra vagy magyarságuk megélésére külföldön, de feltehető, hogy egészen jól integrálódtak a befogadó országba. A kivándorlás véglegessége távolságfüggő. Akik az Egyesült Államokban élnek, egyáltalán nem tervezik a végleges hazatérést Magyarországra, az Egyesült Királyságban élők kétharmada egyáltalán nem tervezi a hazatérést, az Îrországban és Németországban élők fele tervezi, hogy 3-5 éven belül véglegesen hazatér, a másik fele egyáltalán nem. Megállapítható tehát, hogy a nők esetében a migráció földrajzi távolsága összefügg a migráció véglegességével. A hazai szakirodalomban ezzel a távolsághatással még nem találkoztunk, így ezt új eredménynek tekintjük.

Megvizsgáltuk, hogy a migrációs döntés meghozatalakor a nők és a férfiak számára mely tényezők voltak a legfontosabbak és hogy ezek között van-e kap- 
csolat. Az előre megadott tényezőket (lásd az 1. ábrán és a 2. táblázatban) 1-től 5-ig terjedő skálán kellett a válaszadóknak értékelniük. A statisztikai módszerek közül a varianciaelemzést választottuk, amellyel a nem mint független változó hatását vizsgáltuk a migrációs döntés tényezőire mint függő változókra. A varianciaelemzés alkalmazhatóságának feltételei (a függő változó normáleloszlása és a varianciahomogenitás) teljesültek. A vizsgált tényezők közül (5\%-os szignifikanciaszint mellett) a kalandvágy és a pénzkereseti lehetőség bír befolyásoló erővel a vándorlási döntés meghozatalakor; a többi tényező nem.

A nemek között különbségek fedezhetők fel a migráció döntési szemponjai között (1. ábra). A nők a pénzkereseti lehetőségre $(4,2)$ és a nyelvtanulási motivációra $(4,0)$ adták a legmagasabb pontszámokat. A több tapasztalat iráni vágy $(3,7)$ és a pár általi támogatás $(3,5)$ szintén fontos motiváló tényező volt esetükben. A legkevesebb pontot a barátok általi támogatás $(2,0)$ és a szülők támogatása $(2,6)$, valamint a munkanélküliség $(2,6)$ kapták. A férfiaknál eltérőek a motivációk, bár az első helyen náluk is a pénzkereseti lehetőség állt $(4,7)$. A nyelvtanulás $(3,8)$ és a magyarországi kevés munkahely $(3,4)$ tényezőinél mértünk a nőkénél magasabb pontszámokat, a többi tényezőt a férfiak a nőknél kevésbé fontosnak ítélték meg.

A kivándorlás tényezőinek kombinációit faktoranalízissel vizsgáltuk a teljes mintára. A számítások előtt ellenőriztük, hogy az indikátorok megfelelőek-e. Mivel a változók normáleloszlást követtek, a tényezők a Kaiser-Meyer-Olkin-

1. ábra: Milyen motivációi voltak a migrációs döntés meghozatalakor?

What were your motivations for making the migration decision?

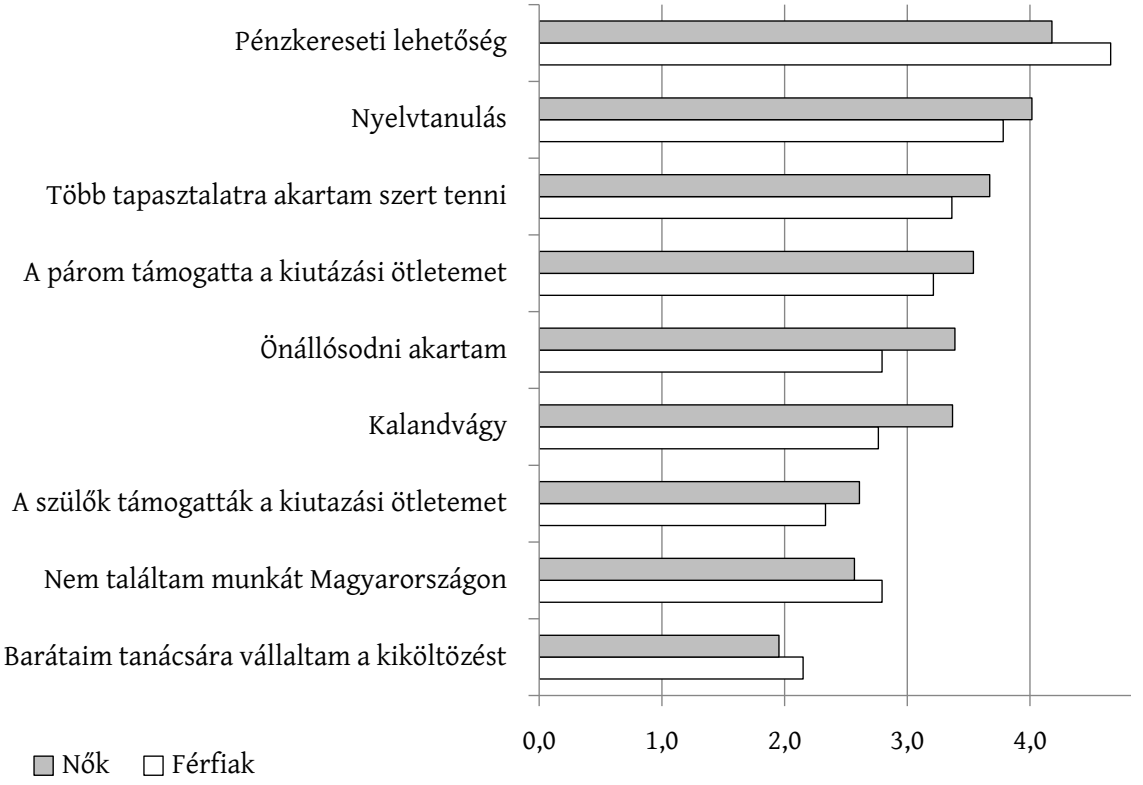


2. táblázat: A faktoranalízis eredményei Results of the factor analysis

\begin{tabular}{lccc}
\hline \multicolumn{1}{c}{ Változók } & \multicolumn{3}{c}{ Faktorok } \\
\cline { 2 - 4 } & Kalandvágy & Kényszermigráció & $\begin{array}{c}\text { Támogatással } \\
\text { rendelkezés }\end{array}$ \\
\hline Több tapasztalatra akartam szert tenni & 0,808 & $-0,140$ & 0,148 \\
Kalandvágy & 0,845 & 0,049 & $-0,123$ \\
Nyelvtanulás & 0,658 & 0,190 & 0,172 \\
Pénzkereseti lehetőség & 0,091 & 0,749 & 0,001 \\
Önállósodni akartam & 0,441 & 0,642 & $-0,048$ \\
Nem találtam munkát Magyarországon & $-0,205$ & 0,717 & 0,117 \\
Barátaim tanácsára vállaltam a kiköltözést & 0,040 & 0,598 & 0,090 \\
A szülők támogatták a kiutazási ötletemet & 0,186 & 0,372 & 0,647 \\
A párom támogatta a kiutazási ötletemet & $-0,002$ & $-0,080$ & 0,890 \\
\hline
\end{tabular}

teszt $(0,667)$ és a Bartlett-féle próba $(140,683)$ alapján korrelálatlanok egymással, a változókészletre alkalmazhatjuk a módszertant (Sajtos, Mitev 2007). A számítások során varimax-rotálást végeztünk Kaiser-féle normalizációval. A faktorok által megmagyarázott variancia 60,3\%. Egy változót akkor tekintünk egy faktor tagjának, ha a faktor súlya legalább 0,5.

Három faktort neveztünk el: (1) kalandvágyók, (2) kényszerből migrálók, (3) támogatással rendelkezők. A kalandvágyók faktora esetében a több tapasztalat, a kalandok és a nyelvtanulás iránti vágy kombinálódik. A kényszerből migrálók körében a pénzkereseti lehetőség, az önállósodás és a magyarországi

2. ábra: Mi volt a kivándorlás oka?

What was your reason for emigration?

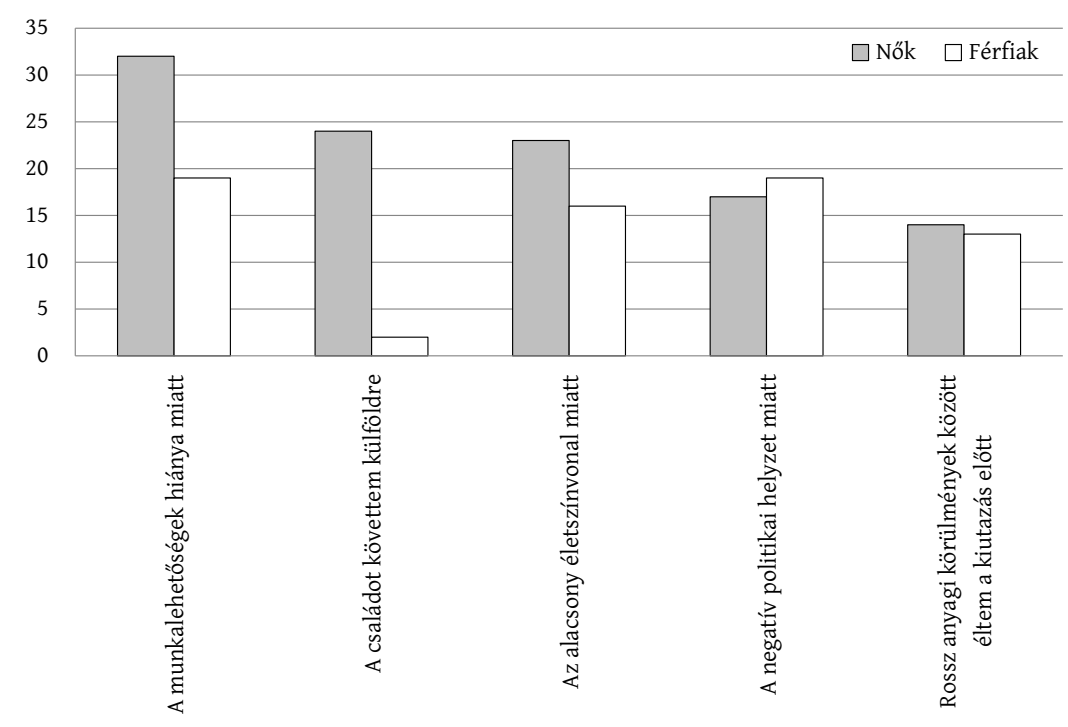


munkalehetőségek hiányának együttese a fő motiváló tényező. A támogatással rendelkezők körében pedig a szülők vagy a családtagok támogatása a legfontosabb, amikor a migráció lehetőségét mérlegelik.

A kivándorlás okaként több tényezőt is megjelölhettek a válaszadók (2. ábra), a nők közül legtöbben a hazai munkalehetőségek hiányát jelölték meg, majd azt, hogy a családot követték a kivándorlással és végül az alacsony hazai életszínvonalat. A férfiak válaszaiban ehhez képest jelentős eltérés figyelhető meg, ők a negatív politikai helyzetet, a munkalehetőségek hiányát és az alacsony életszínvonalat jelölték meg főbb kivándorlási okként.

\section{Összegzés}

Kérdőives felmérésünk alapján megállapítható, hogy a vizsgálatban szereplő magyar nők kivándorlásában a tapasztalatszerzés iránti vágy és az itthoni munkalehetőségek hiánya a fö motivációs tényező. Többségük házas vagy kapcsolatban él és a Magyarországra való visszatérést csak fontolgatják. Körükben a mobilitáshoz vezető döntési folyamatban a férfiak (párjuk, házastársuk) nagy szerepét tudtuk kimutatni. Az egyedülálló nők általában fiatalabbak és határozottan vissza akarnak térni Magyarországra pár év külföldi munkavállalás után. A kutatás távolsághatást is kimutatott: azok a nők, akik földrajzilag Magyarországtól jóval messzebbre migráltak, véglegesnek tekintik a migrációt és nem fontolják a hazatérést.

A további kutatásunkban a Magyarországról külföldre vándorlók körében a Super-féle munkaérték-kérdőívet kívánjuk kitöltetni. E vizsgálat rávilágíthat arra, hogy a megkérdezettek milyen értékrenddel rendelkeznek a (formális) munka világáról, melyek azok az értékek, melyek a személyiségüket jellemzik a munkavégzés során, illetve van-e eltérés az értékelemekben nemek szerint.

A kutatás jövőbeli folytatásaként célszerü mélyinterjút is készíteni a külföldön élő nőkkel, hogy még több információt megtudjunk a kivándorlási döntésről, a migrációs folyamatról, a tapasztalatokról, valamint a bérmunka mellett a társadalmi reprodukcióban a női szerepekről. Ezzel a szakirodalom által is szorgalmazott módon kvalitatív vizsgálatokkal egészíthetjük ki az itt bemutatott kvantitatív elemzést.

\section{Irodalom}

Cantu, L. (2001): A place called home: A queer political economy of Mexican immigrant men's family experiences. In: Bernstein, M., Rieimann, R. (eds.): Queer families, queer politics. Columbia Universty Press, New York, 112-136.

Choudhury, T. (2013): Experiences of women as workers: A study of construction workers in Bangladesh. Construction Management and Economics, 8., 883-898. http://doi.org/cffd 
Choudhury, T. (2017): Women and migration: transition, agency andlabour. Journal of Alternative Perspectives in the Social Sciences, 3., 299-322.

Curran, S. R., Shafer, S., Donato, K. M., Garip, F. (2006): Mapping gender and migration in sociological scholarship: Is it segregation or integration? International Migration Review, 1., 199-223. http://doi.org/dv73mc

Cseres-Gergely Zs. (2003): Elméleti megfontolások a munkavállalók területi mozgásának okaival és eredményével kapcsolatban. In: Fazekas K. (szerk.): Munkaeröpiaci Tükör 2003. MTA Közgazdaságtudományi Kutatóközpont, Országos Foglalkoztatási Közalapítvány, Budapest, 51-56.

Dabasi-Halász Zs. (2009): Nyertesek és vesztesek! A nemzetközi migráció stratégiai tényezői és tendenciái Borsod-Abaúj-Zemplén megyében. PhD-értekezés. Miskolci Egyetem, Miskolc

Gödri I. (2005): Nők és férfiak a migrációs folyamat különbözőszakaszaiban. A magyarországi bevándorlás a nemek perspektívájából In: Nagy I., Pongrácz T., Tóth I. Gy. (szerk.): Szerepváltozások. Jelentés a nők és férfiak helyzetéról. TÁRKI, Ifjúsági, Családügyi, Szociális és Esélyegyenlőségi Minisztérium, Budapest, 149-164.

Gödri I. (2010): Migráció a kapcsolatok hálójában. Központi Statisztikai Hivatal Népességtudományi Kutatóintézet, Budapest (Központi Statisztikai Hivatal Népességtudományi Kutatóintézetének Kutatási Jelentései; 89.)

Grossman-Thompson, B. (2016): Protection and paternalism: narratives of Nepali women migrants and the gender politics of discriminatory labour migration policy. Refuge, 3., 40-48.

Hautzinger Z., Hegedüs J., Klenner Z. (2014): A migráció elmélete. Nemzeti Közszolgálati Egyetem, Budapest

Hondagneu-Sotelo, P. (2000): Feminism and migration. The Annals of the American Academy of Political and Social Science, 1., 107-119. http://doi.org/cffg

Indra, D. (1999): Not a "room of one's own:" Engendering forced migration knowledge and practice. In: Indra, D. (ed.): Engendering forced migration: Theory and practice, Berghahn Books, New York, $1-22$.

Jesmin, S., Salway, S. (2000): Marriage among the urban poor of Dhaka: instability and uncertainty. Journal of International Development, 5., 689-705. http://doi.org/fkdhkv

Kabeer, N., Mahmud, S. (2004): Globalisation, gender and poverty: Bangladeshi women workers in export and local markets. Journal of International Development, 1., 93-109. http://doi.org/c9gzbh

Kofman, E., Phizacklea, A., Raghuram, P., Sales, R. (2000): Gender and international migration in Europe: Employment, welfare and politics. Routledge, London

Melegh A., Kovács Á., Gödri I. (2009): „Azt hittem célt tévesztettem.” A bevándorló nók élettörténeti perspektivái, integrációja és a bevándorlókkal kapcsolatos attitüdök nyolc európai országban. Központi Statisztikai Hivatal Népességtudományi Kutatóintézet, Budapest (Központi Statisztikai Hivatal Népességtudományi Kutatóintézetének Kutatási Jelentései; 88.)

Michalitsch, G. (2011): ArbeitsPolitik: Keine Freiheit ohne Gleichheit. Zukunft: Die Diskussionszeitschrift für Politik, Gesellschaft und Kultur, 1., 38-44.

Moch, L. P. (2005): Gender and migration research. In: Bommes, M., Morawska E. (eds.): International migration research: Constructions, omissions and the promises of interdisciplinarity. Ashgate, Aldershot, 95-108.

Momsen, J. (1993): Women and development in the Third World. Routledge, London

Nawyn, S. J. (2010): Gender and migration: Integrating feminist theory into migration studies. Sociology Compass, 9., 749-765. http://doi.org/dqz33q

Oso, L., Ribas-Mateos, N. (2013): The international handbook on gender, migration and transnationalism: Global and development perspectives. Edward Elgar Publishing, Cheltenham http://doi.org/cbbg

Sajtos L., Mitev A. (2007): SPSS kutatási és adatelemzési kézikönyv. Aliena Kiadó, Budapest

Todd, G., Clark, B., Marston, M., Urassa, M., Todd, J. (2017): Gender and youth migration for empowerment: migration trends from Tanzania. Migration Letters, 2., 300-317. 